\title{
Comparison of haemodynamic effects of intravenous isoprenaline and adrenaline after aortic valvar homograft replacement
}

\author{
R. M. M. Fordham ${ }^{1}$ and Leon Resnekov ${ }^{2}$ \\ From The Institute of Cardiology, National Heart Hospital, London W.I, and the \\ Department of Anaesthetics, St. Thomas' Hospital, London S.E.I
}

The cardiovascular effects of an intravenous infusion of adrenaline (1o $\mu \mathrm{g} . / \mathrm{min}$.) and isoprenaline $(0.75 \mu \mathrm{g} . / \mathrm{min}$.$) have been compared in two groups of six patients in the early post-operative period$ following aortic valvar homograft replacement. These doses were chosen to produce obvious haemodynamic effects without precipitating dysrhythmias. Though both drugs have been shown to improve the circulatory state, adrenaline caused a greater change in stroke volume and in arterial pulse pressure, and for any given rise in heart rate a greater increase in the cardiac index. In addition, adrenaline caused a greater improvement in the relation between oxygen demand and oxygen supply of the body. Isoprenaline did not cause an increase in systolic and pulse pressure and always aggravated hypoxaemia. It is concluded from this study that adrenaline is the more satisfactory drug to use in the early post-operative phase following aortic valvar homograft replacement.

The haemodynamic effects of intravenous adrenaline and isoprenaline have been studied in normal subjects (Gorten et al., 1961; Weissler, Leonard, and Warren, 1959; Harrison et al., 1964; Allwood et al., 1962; Barcroft and Starr, 195I; Cyvin et al., 1955; Goldberg et al., 1960; Dodge, Lord, and Sandler, 1960) and in diseased states (Bruce et al., 1961 ; Benchimol, Lucena, and Dimond, 1965; Cox, Cobb, and Bruce, 1963; Witham and Fleming, I95I), including congestive heart failure (Dodge et al., 1960; Dodge and Murdaugh, 1957). The results of these studies have been used to predict the haemodynamic changes that will follow their administration when used to treat low cardiac output states in the post-operative period after open-heart surgery (Moffitt, Sessler, and Kirklin, 1967). In this paper we wish to document the cardiovascular effects during an intravenous infusion of adrenaline and isoprenaline after aortic valvar homograft replacement and to compare the effects of the two drugs in detail to determine which is preferable in the postoperative period.

Received 29 October 1969.

1 Present address: Nuffield Department of Anaesthesia, Radcliffe Infirmary, Oxford.

2 Present address : Department of Medicine (Cardiology), University of Chicago, 950 East 59th Street, Chicago, IIl. 60637, U.S.A.

Requests for reprints should be addressed to Dr. Resnekov.

\section{Subjects and methods}

Twelve patients were studied 16 to 20 hours after aortic valvar homograft replacement, 6 of whom were given intravenous isoprenaline and 6 intravenous adrenaline. The clinical details of the patients studied are listed in Table r. One patient

TABLE I Clinical details of patients studied

\begin{tabular}{|c|c|c|c|}
\hline $\begin{array}{l}\text { Case } \\
\text { No. }\end{array}$ & $\begin{array}{l}\text { Age }(y r .) \\
\text { and sex }\end{array}$ & Disease & Operation \\
\hline \multicolumn{4}{|c|}{ Isoprenaline } \\
\hline $\mathbf{I}$ & $39, \mathrm{M}$ & $\begin{array}{l}\text { Aortic stenosis and } \\
\text { regurgitation }\end{array}$ & Aortic valvar homograft \\
\hline 2 & 49, M & Aortic regurgitation & Aortic valvar homograft \\
\hline 3 & $56, F$ & $\begin{array}{l}\text { Aortic stenosis and regurgi- } \\
\text { tation, mitral stenosis }\end{array}$ & $\begin{array}{l}\text { Aortic valvar homograft, } \\
\text { closed mitral valvotomy }\end{array}$ \\
\hline 4 & $54, M$ & $\begin{array}{l}\text { Aortic stenosis and } \\
\text { regurgitation }\end{array}$ & Aortic valvar homograft \\
\hline 5 & $44, M$ & $\begin{array}{l}\text { Aortic stenosis and } \\
\text { regurgitation }\end{array}$ & Aortic valvar homograft \\
\hline 6 & $4 \mathrm{I}, \mathrm{M}$ & $\begin{array}{l}\text { Aortic regurgitation, mitral } \\
\text { stenosis and regurgitation }\end{array}$ & $\begin{array}{l}\text { Aortic valvar homograft, } \\
\text { mitral valvar decalcifica- } \\
\text { tion }\end{array}$ \\
\hline \multicolumn{4}{|c|}{ Adrenaline } \\
\hline $\begin{array}{l}7 \\
8\end{array}$ & $\begin{array}{l}57, M \\
32, M\end{array}$ & $\begin{array}{l}\text { Aortic stenosis } \\
\text { Aortic stenosis, mitral } \\
\text { stenosis }\end{array}$ & $\begin{array}{l}\text { Aortic valvar homograft } \\
\text { Aortic valvar homograft, } \\
\text { closed mitral valvotomy }\end{array}$ \\
\hline 9 & $64, M$ & Aortic stenosis & Aortic valvar homograft \\
\hline I0 & 27, M & $\begin{array}{l}\text { Aortic stenosis and } \\
\text { regurgitation }\end{array}$ & Aortic valvar homograft \\
\hline I I & $62, M$ & $\begin{array}{l}\text { Aortic stenosis and } \\
\text { regurgitation }\end{array}$ & Aortic valvar homograft \\
\hline 12 & $64, M$ & $\begin{array}{l}\text { Aortic stenosis and } \\
\text { regurgitation }\end{array}$ & Aortic valvar homograft \\
\hline
\end{tabular}


TABLE 2 Mean control values and changes in measured and calculated parameters following ro minutes adrenaline and isoprenaline infusion while continuing infusion

\begin{tabular}{|c|c|c|c|c|c|c|c|}
\hline & $\begin{array}{l}\mathrm{O}_{2} \text { consump. } \\
(\mathrm{ml} \text {./min. })\end{array}$ & $\begin{array}{l}\text { Art. } \mathrm{O}_{2} \\
\text { content } \\
\text { (vol. } \% \text { ) }\end{array}$ & $\begin{array}{l}\text { Pulm. art. } \mathrm{O}_{2} \\
\text { content } \\
(\text { vol. } \%)\end{array}$ & $\begin{array}{l}A V O_{2} \text { diff. } \\
\text { (vol. } \% \text { ) }\end{array}$ & $\begin{array}{l}\text { Cardiac index } \\
\left(l . / \min . / m .^{2}\right)\end{array}$ & $\begin{array}{l}\text { Heart rate } \\
\text { (beats/min.) }\end{array}$ & $\begin{array}{l}\text { Stroke index } \\
\left(m l . \mid m .^{2}\right)\end{array}$ \\
\hline $\begin{array}{l}\text { Isoprenaline (6) } \\
\text { Control }\end{array}$ & $\begin{array}{l}255 \\
(33)\end{array}$ & $\begin{array}{l}16 \cdot 8 \\
(I \cdot 3)\end{array}$ & $\begin{array}{l}9 \cdot 4 \\
(I \cdot 3 I)\end{array}$ & $\begin{array}{c}7 \cdot 4 \\
(0 \cdot 78)\end{array}$ & $\begin{array}{c}2.03 \\
(0.20)\end{array}$ & $\begin{array}{l}90 \\
(18 \cdot 9)\end{array}$ & $\begin{array}{l}23 \\
(4 \cdot 5)\end{array}$ \\
\hline 0.75 ( $\mathrm{gg} . / \mathrm{min})$. & $\begin{array}{l}273 \\
(23)\end{array}$ & $\begin{array}{l}I 6 \cdot I \\
(I \cdot 6)\end{array}$ & $\begin{array}{l}9 \cdot 9 \\
(1 \cdot 31)\end{array}$ & $\begin{array}{c}6.2 \\
(0.92)\end{array}$ & $\begin{array}{c}2.63 \\
(0.44)\end{array}$ & $\begin{array}{l}\text { I09 } \\
(14 \cdot 3)\end{array}$ & $\begin{array}{l}24 \\
(4 \cdot 7)\end{array}$ \\
\hline $\begin{array}{l}\text { Change } \\
\% \text { Change } \\
\text { p }\end{array}$ & $\begin{array}{r}+18 \\
+7 \\
\text { N.S. }\end{array}$ & $\begin{array}{l}-0.7 \\
-4 \\
<0.01\end{array}$ & $\begin{array}{l}+0.5 \\
+6 \\
<0.01\end{array}$ & $\begin{array}{l}-1.2 \\
-.16 \\
<0.01\end{array}$ & $\begin{array}{l}+0.60 \\
+30 \\
<0.01\end{array}$ & $\begin{array}{l}+19 \\
+21 \\
<0.0 I\end{array}$ & $\begin{array}{r}+1 \\
+4 \\
\text { N.S. }\end{array}$ \\
\hline $\begin{array}{l}\text { Adrenaline (6) } \\
\text { Control }\end{array}$ & $\begin{array}{l}229 \\
(27)\end{array}$ & $\begin{array}{l}17: 3 \\
(2 \cdot 64)\end{array}$ & $\begin{array}{c}9 \cdot 3 \\
(I \cdot 99)\end{array}$ & $\begin{array}{l}7 \cdot 9 \\
(I \cdot 5 I)\end{array}$ & $\begin{array}{c}I \cdot 67 \\
(0.35)\end{array}$ & $\begin{array}{c}93 \cdot 7 \\
(20 \cdot 3)\end{array}$ & $\begin{array}{r}18 \cdot 3 \\
4 \cdot 8\end{array}$ \\
\hline IO $\mathrm{\mu g} / \mathrm{min}$. & $\begin{array}{l}275 \\
(35)\end{array}$ & $\begin{array}{l}16 \cdot 8 \\
(2 \cdot 47)\end{array}$ & $\begin{array}{l}10.5 \\
(2 \cdot 30)\end{array}$ & $\begin{array}{l}6 \cdot 4 \\
(1.0 I)\end{array}$ & $\begin{array}{c}2.48 \\
(0.46)\end{array}$ & $\begin{array}{l}106 \cdot 7 \\
(2 \mathrm{I} \cdot 8)\end{array}$ & $\begin{array}{l}23 \cdot 8 \\
(4 \cdot 8)\end{array}$ \\
\hline $\begin{array}{l}\text { Change } \\
\% \text { change } \\
\text { p }\end{array}$ & $\begin{array}{l}+46 \\
+20 \\
<0.01\end{array}$ & $\begin{array}{l}-0.5 \\
-3 \\
\text { N.S. }\end{array}$ & $\begin{array}{l}+\mathrm{I} \cdot 2 \\
+10 \\
<0.01\end{array}$ & $\begin{array}{l}-1 \cdot 5 \\
-20 \\
<0.01\end{array}$ & $\begin{array}{l}+0.81 \\
+48 \\
<0.01\end{array}$ & $\begin{array}{l}+13 \\
+14 \\
<0.01\end{array}$ & $\begin{array}{l}+5.5 \\
+33 \\
<0.01\end{array}$ \\
\hline
\end{tabular}

(Case 12, adrenaline series) had been in a worse condition before operation than the others; he had been in severe left ventricular failure, had survived two episodes of cardiac arrest, and was hypoxaemic at the time of study. All the patients, however (including Case 12), were in a satisfactory clinical condition during this study, and none required additional supportive measures other than routine post-operative care. All were in sinus rhythm before and during the drug infusions.

Details of the methods of study have been previously described (Resnekov, Fordham, and Ross, 1968; Fordham, Resnekov, and Paddle, r968). In brief, the following measurements were made before and during the drug infusion: oxygen consumption, arterial (ascending aorta) and mixed venous blood oxygen content (pulmonary artery), heart rate, systemic arterial, pulmonary arterial, and right atrial pressures. The arteriovenous oxygen difference, cardiac output (Fick principle), left ventricular stroke work, left ventricular minute work, and their indices, and the total peripheral resistance were calculated from the measurements as listed using standard formulae. The effects of an infusion of adrenaline (ro $\mu \mathrm{g} . / \mathrm{min}$.) and isoprenaline ( $0.75 \mu \mathrm{g} . / \mathrm{min}$.) were compared after Io minutes of administration of each drug and while the infusion continued, and the results were analysed for statistical significance using the Student's ' $t$ ' test (Bradford Hill, r966).

\section{Results}

The mean control values, mean values during infusions of isoprenaline and adrenaline, and the mean changes in the measured and calculated parameters for each drug, as well as their statistical significance, are shown in Table 2. The changes from the control values during the infusion of the two drugs are compared in Fig. I, in which the statistical significance of the differences between the effects of the two drugs is also given.

Despite the small numbers of the patients in each group, a statistically significant difference $(p<0.01)$ was found between the two drugs for changes in the stroke index (isoprenaline $+1.0 \mathrm{ml} . / \mathrm{m}^{2}$, adrenaline +5.5 $\mathrm{ml} . / \mathrm{m}^{2}$ ) and arterial pulse pressure (isoprenaline $+3 \mathrm{~mm}$. $\mathrm{Hg}$, adrenaline $+3 \mathrm{I} \mathrm{mm}$. $\mathrm{Hg}$ ). Probable significant differences $(\mathrm{p}<$ 0.05 ) were found for mean changes in arterial systolic pressure (isoprenaline $+3 \mathrm{~mm}$. $\mathrm{Hg}$, adrenaline $+30 \mathrm{~mm}$. $\mathrm{Hg}$ ), total peripheral resistance (isoprenaline -223 dynes sec. $\mathrm{cm} .^{-5}$, adrenaline -572 dynes sec. $\mathrm{cm} .^{-5}$ ) and left ventricular stroke work index (isoprenaline +2.4 g.m. $/ \mathrm{m}^{2}$, adrenaline +8.9 g.m. $/ \mathrm{m}^{2}$ ). Variable increases were found in the heart rate in the two groups, though during infusion of isoprenaline the increase in heart rate was found to be inversely related to the control value (Resnekov et al., I968), a relation that did not occur during the infusion of adrenaline. The mean heart rate increase was slightly greater during infusion of isoprenaline ( +19 beats/min.), than during infusion of adrenaline ( $+I_{3}$ beats/min.) at the doses employed. Greater mean changes in cardiac index, oxygen 


\begin{tabular}{|c|c|c|c|c|c|c|c|c|c|}
\hline $\begin{array}{l}\text { Brachial } \\
\text { Systolic }\end{array}$ & $\begin{array}{l}\text { artery pressur } \\
\text { Diastolic }\end{array}$ & $\underset{\text { Mean }}{\operatorname{emm} . H g)}$ & $\begin{array}{l}\text { Pulse } \\
\text { pressure } \\
\text { (mm. Hg) }\end{array}$ & $\begin{array}{l}\text { Mean pulm. } \\
\text { art. pressure } \\
(\mathrm{mm} . \mathrm{Hg})\end{array}$ & $\begin{array}{l}\text { Mean right } \\
\text { atrial pressure } \\
(\mathrm{mm} . \mathrm{Hg})\end{array}$ & $\begin{array}{l}L V \text { stroke } \\
\text { work index } \\
\left(\text { g.m. } / m^{2} .^{2}\right)\end{array}$ & $\begin{array}{l}L V \text { minute } \\
\text { work index } \\
\left(\mathrm{g} . \mathrm{m} . / \mathrm{m} .{ }^{2}\right)\end{array}$ & $\begin{array}{l}\text { Total periph. } \\
\text { resist. }(\text { dynes. } \\
\left.\text { sec. } \text { cm. }^{-5}\right)\end{array}$ & \\
\hline $\begin{array}{l}115 \\
(27)\end{array}$ & $\begin{array}{l}64.5 \\
\text { (10) }\end{array}$ & $\begin{array}{l}77 \\
(12 \cdot 5)\end{array}$ & $\begin{array}{l}50 \\
(18 \cdot 5)\end{array}$ & $\begin{array}{l}17 \cdot 5 \\
(4 \cdot 7)\end{array}$ & $\begin{array}{c}6.6 \\
(2 \cdot 8)\end{array}$ & $\begin{array}{l}21 \cdot 5 \\
(5 \cdot 4)\end{array}$ & $\begin{array}{c}I \cdot 91 \\
(0.45)\end{array}$ & $\begin{array}{l}1586 \\
(388)\end{array}$ & $\begin{array}{l}\text { Isoprenaline (6) } \\
\text { Control }\end{array}$ \\
\hline $\begin{array}{l}\text { I18 } \\
(27)\end{array}$ & $65 \cdot 5$ & $\begin{array}{l}80 \\
(13 \cdot 8)\end{array}$ & $\begin{array}{l}53 \\
(18 \cdot 0)\end{array}$ & $\begin{array}{l}17 \cdot 0 \\
(4 \cdot 8)\end{array}$ & $\begin{array}{l}4 \cdot 0 \\
(2 \cdot 5)\end{array}$ & $\begin{array}{c}23 \cdot 9 \\
(5 \cdot 1)\end{array}$ & $\begin{array}{l}2.56 \\
(0.52)\end{array}$ & $\begin{array}{l}1363 \\
(416)\end{array}$ & 0.75 ( $\mu \mathrm{g} . / \mathrm{min})$. \\
\hline $\begin{array}{r}+3 \\
+2 \\
\text { N.S. }\end{array}$ & $\begin{array}{l}+\mathbf{I} \\
+\mathrm{I} \\
\text { N.S. }\end{array}$ & $\begin{array}{l}+3 \\
+4 \\
\text { N.S. }\end{array}$ & $\begin{array}{r}+3 \\
+6 \\
\text { N.S. }\end{array}$ & $\begin{array}{l}-0.5 \\
-3 \\
\text { N.S. }\end{array}$ & $\begin{array}{l}-2 \cdot 6 \\
-39 \\
\text { N.S. }\end{array}$ & $\begin{array}{l}+2 \cdot 4 \\
+11 \\
\text { N.S. }\end{array}$ & $\begin{aligned} & 0.55 \\
+ & 34 \\
< & 0.01\end{aligned}$ & $\begin{array}{l}-223 \\
-14 \\
<0.05\end{array}$ & $\begin{array}{l}\text { Change } \\
\% \text { change } \\
\text { p }\end{array}$ \\
\hline $\begin{array}{l}122 \\
(13.9)\end{array}$ & $\begin{array}{l}77 \\
(12 \cdot 1)\end{array}$ & $\begin{array}{l}86 \\
(\mathrm{II} \cdot 8)\end{array}$ & $\begin{array}{l}45 \\
(8 \cdot 2)\end{array}$ & $\begin{array}{l}16 \cdot 6 \\
(6 \cdot 4)\end{array}$ & $\begin{array}{l}5 \cdot 2 \\
(1 \cdot 33)\end{array}$ & $\begin{array}{l}19 \cdot 3 \\
(5 \cdot 5)\end{array}$ & $\begin{array}{l}I \cdot 79 \\
(0.51)\end{array}$ & $\begin{array}{l}2232 \\
(382)\end{array}$ & $\begin{array}{l}\text { Adrenaline (6) } \\
\text { Control }\end{array}$ \\
\hline $\begin{array}{l}152 \\
(22.9)\end{array}$ & $\begin{array}{l}76 \\
(12 \cdot 6)\end{array}$ & $\begin{array}{l}93 \\
(15 \cdot 1)\end{array}$ & $\begin{array}{l}76 \\
(13 \cdot 7)\end{array}$ & $\begin{array}{l}18 \cdot 6 \\
(8 \cdot 2)\end{array}$ & $\begin{array}{l}3.6 \\
(0.85)\end{array}$ & $\begin{array}{c}28 \cdot 2 \\
(8 \cdot 4)\end{array}$ & $\begin{array}{c}2.93 \\
(0.83)\end{array}$ & $\begin{array}{l}1660 \\
(296)\end{array}$ & Io $\mu \mathrm{g} . / \mathrm{min}$. \\
\hline $\begin{array}{l}+30 \\
+25 \\
<0.05\end{array}$ & $\begin{array}{l}-I \\
-I \\
\text { N.S. }\end{array}$ & $\begin{array}{l}+7 \\
+8 \\
\text { N.S. }\end{array}$ & $\begin{array}{l}+31 \\
+69 \\
<0.01\end{array}$ & $\begin{array}{l}+2 \cdot 0 \\
+12 \\
\text { N.S. }\end{array}$ & $\begin{array}{l}-1 \cdot 6 \\
-31 \\
\text { N.S. }\end{array}$ & $\begin{array}{l}+8.9 \\
+46 \\
<0.05\end{array}$ & $\begin{array}{l}+1 \cdot 14 \\
+64 \\
<0 \cdot 01\end{array}$ & $\begin{array}{l}-572 \\
-26 \\
<0.01\end{array}$ & $\begin{array}{l}\text { Change } \\
\% \text { change } \\
\text { p }\end{array}$ \\
\hline
\end{tabular}

consumption, arteriovenous oxygen difference, mixed venous oxygen content, and left ventricular minute work were found during adrenaline than during isoprenaline infusion, though the differences between these changes were not statistically significant. Isoprenaline had very little effect on the arterial systolic, diastolic, mean, or pulse pressures.

\section{Discussion}

The two groups of patients studied were comparable (Table I), though the mean agegroup was slightly higher in the adrenaline series ( 51 years as compared with 47 years) and the average control cardiac index lower in the adrenaline series $\left(1.671 . / \mathrm{min} . / \mathrm{m}^{2}\right.$ versus $2.031 . / \mathrm{min} . / \mathrm{m}^{2}{ }^{2}$ ). All $\mathrm{I} 2$ patients were considered to be in a satisfactory condition before the study started and none required additional supportive therapy. Both adrenaline and isoprenaline caused a rise in the cardiac index (Table 2), but the difference between the effects of the two drugs failed to achieve statistical significance (Fig. I). Infusion of both drugs caused feelings of anxiety in the patients studied, and in addition repeated collections of expired air were not conducive to maintaining the steady state. For these reasons, it was decided not to attempt to compare the effects of both drugs on each patient, but to use two groups of comparable patients studied in an identical fashion at a similar period of time following aortic valvar homograft replacement, except that in the one group adrenaline would be used and in the other isoprenaline. Furthermore, the effects of an infusion of either isoprenaline or adrenaline often persist for a longer time than is immediately apparent (Cyvin et al., 1955), making a true comparison difficult if the drugs are infused consecutively in the same patient. Another point of considerable importance is whether the doses of the two drugs used were strictly comparable. In previous reports where the effects of serial increases in the dosages of adrenaline and isoprenaline were studied (Resnekov et al., 1968; Fordham et al., 1968), it was found that higher doses often precipitated potentially dangerous dysrhythmias. A dose of isoprenaline of $0.75 \mu \mathrm{g} . / \mathrm{min}$. and of adrenaline of Io $\mu \mathrm{g}$./min. was therefore being used in this study, for it was shown that these doses produced consistent haemodynamic changes without precipitating any rhythm disturbance. Both isoprenaline and adrenaline caused tachycardia, and we have, therefore, compared the haemodynamic effects produced by the two drugs in respect of changes in heart rate. This approach has the additional practical advantage of indicating which drug is likely to improve the cardiovascular status of these patients most without causing too large an increase in heart rate.

The main distinction between the action of the two drugs depends on their different 
FIG. I Individual and mean changes in measured and calculated parameters during adrenaline $(O)$ and isoprenaline $(O)$ infusion. Mean values are indicated by short horizontal lines. ' $P$ ' values indicate the statistical signifcance of the difference between the effects of the two drugs. - Case 12, adrenaline series. His response differed from the other five in all respects and could relate to hypoxaemia (arterial oxygen saturation $81 \%$ ) reducing the effects of circulatory catecholamines (Greene and Phillips, 1957). Case I2 has been identified in all the figures by this symbol. $H R$, heart rate; CI, cardiac index; SI, stroke index; $\dot{V} o_{2}$ oxygen consumption; $a-\bar{V} D O_{2}$, arteriovenous oxygen difference; $B A$, brachial arterial pressure; $S$, systolic; $d$, diastolic; $m$, mean; $p$, pulse pressure; $C \bar{V} o_{2}$, oxygen content mixed venous blood; TPR, total peripheral resistance; LVSWI, left ventricular stroke work index; LVMWI, left ventricular minute work index; NS, not significant at 5 per cent level.

effects on stroke volume. Individual changes in cardiac index plotted against changes in heart rate are shown in Fig. 2. As can be seen, for any given rise in heart rate there was generally a greater increase in cardiac index produced by adrenaline than by isoprenaline (except for Case 12). This finding is explained by the increase in stroke index induced by adrenaline, but not by isoprenaline. We have previously shown that a given dose of isoprenaline will produce a larger rise in heart rate and cardiac index when the control heart rate is slow than when it is rapid (Resnekov et al., 1968), whereas no such relation was found with adrenaline. Furthermore, adrenaline seems the more effective drug in increasing the cardiac output when reduced. This is especially true when the control heart rate is high and the cardiac output low; a satisfactory increase in cardiac output may require higher doses of isoprenaline than used in this study and precipitate dysrhythmias.

The greater increase in cardiac output for a given rise in heart rate produced by adrenaline is reflected in the changes in the arteriovenous oxygen difference. From Fig. $3 a$ it can be seen that, when compared to changes in heart rate, adrenaline produces a greater fall in arteriovenous oxygen difference than does isoprenaline, and that the magnitude of this fall is related to the change in cardiac index (Fig. 3b), irrespective of the drug used. Since the arteriovenous oxygen difference is an index of the relation between supply and
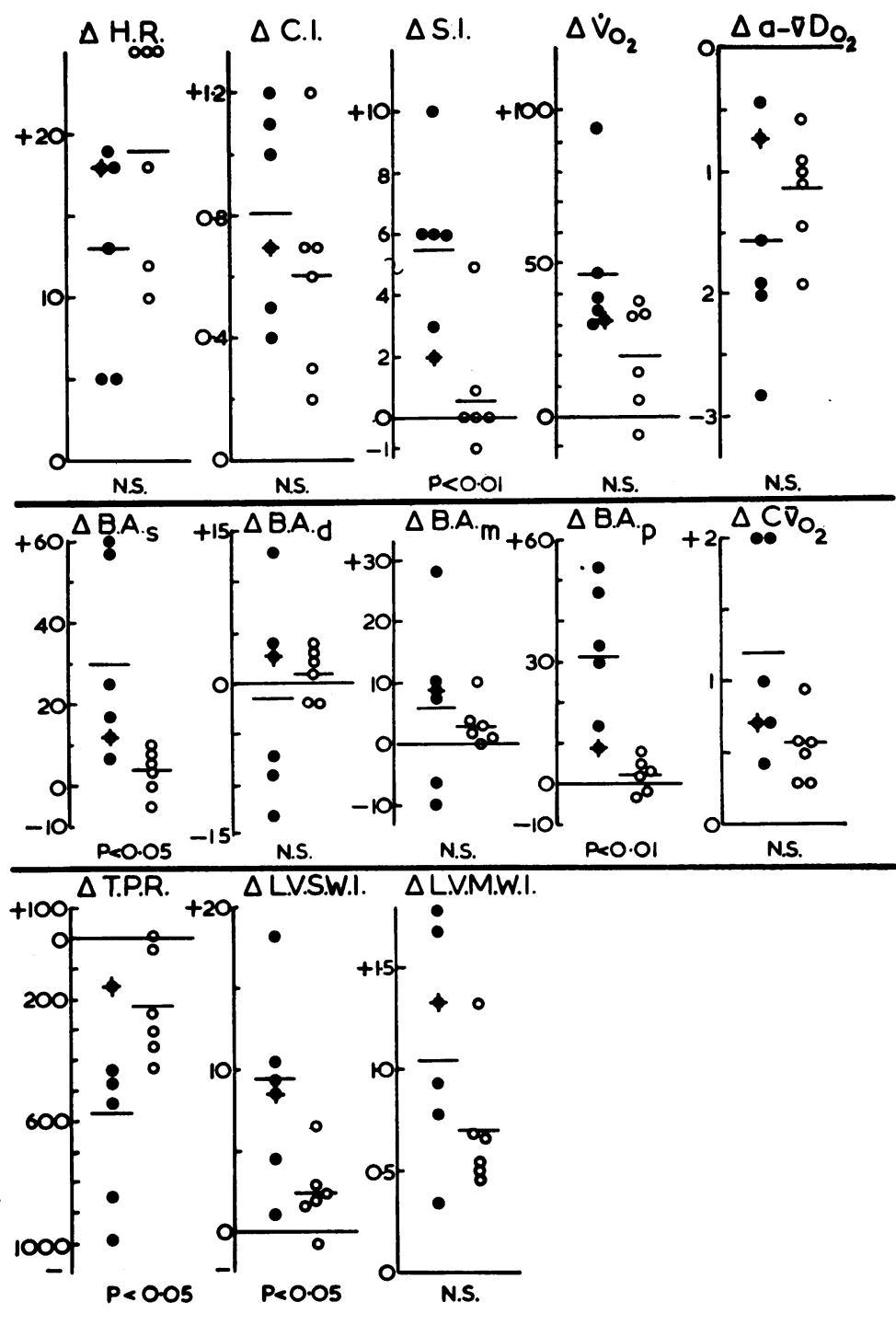

demand of oxygen in the tissues, adrenaline causes a greater improvement in oxygen supply to the body, in relation to demand, for any given increase in heart rate.

Differences were found in the effects of the two drugs on brachial artery systolic and pulse pressures (Fig. 4). Adrenaline caused a rise in these parameters, with no associated changes in diastolic or mean pressures. No consistent changes were caused by isoprenaline. In Fig. 4 it can be seen that increases in pulse pressure are linearly related to increases in stroke index, which suggests that the absence of any change in pulse pressure during isoprenaline infusion is secondary to its lack of effect on the stroke volume.

The relation between changes in total peripheral resistance and changes in heart 


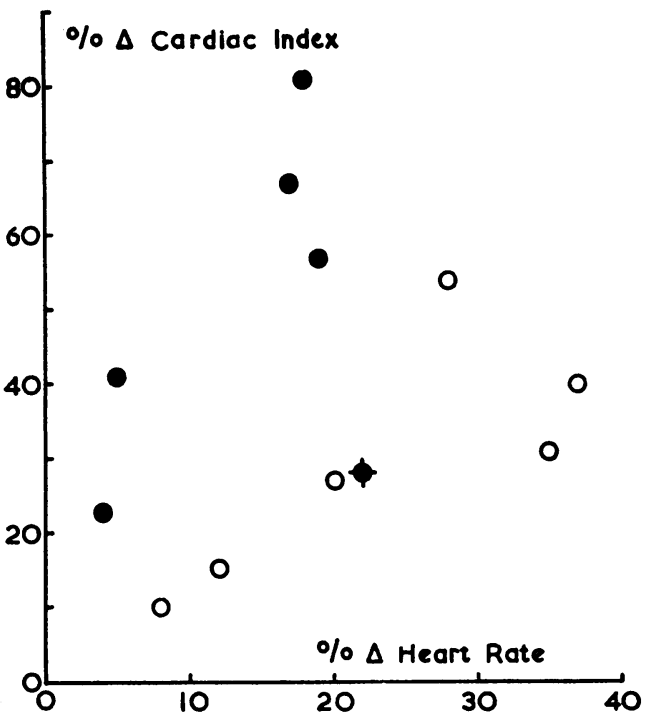

FIG. 2 Changes in cardiac index (l./min./m. $)^{2}$ plotted against changes in heart rate (beats/min.) during adrenaline and isoprenaline infusion. Symbols as in Fig. I. A linear relation was found between the two parameters during isoprenaline infusion $(r=0.7697$; $t=2.4 I I ; p<0.05)$.

FIG. $3 \mathrm{a}$ and $3 \mathrm{~b}$ Changes in arteriovenous oxygen difference $\left(a-\bar{v} \mathrm{Do}_{2} ;\right.$ vol. $\left.\%\right)$ plotted against changes in heart rate (beats/min.) (Fig. $3 a$ ) and cardiac index (i./min./m. ${ }^{2}$ ) (Fig. $3 b$ ) during adrenaline and isoprenaline infusion. Symbols as in Fig. I. (For all points plotted in Fig. $3 b, r=0.8060 ; t=4 \cdot 305$; $p<0.01$.)

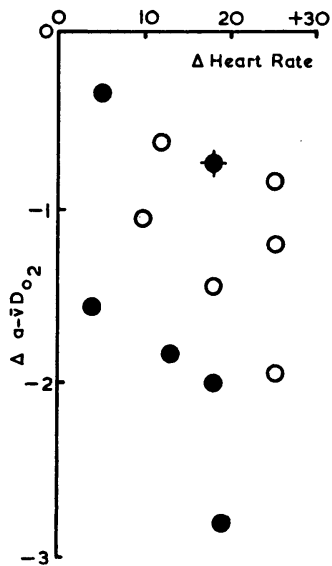

(a)

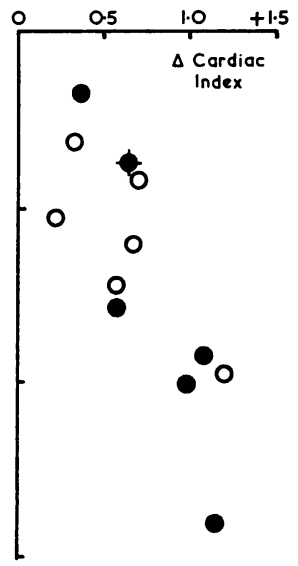

(b)

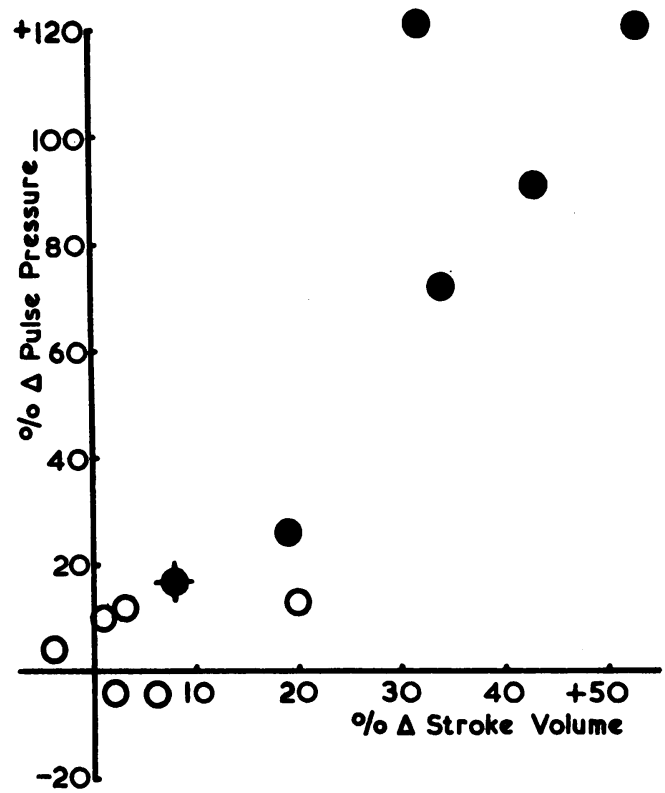

FIG. 4 Changes in brachial arterial pulse pressure $(\mathrm{mm} . \mathrm{Hg}$ ) plotted against changes in stroke volume (ml.) during infusion of adrenaline and isoprenaline. Symbols as in Fig. $I$. $A$ linear relation was found between the two parameters (for all points plotted, $r=0.9086$; $t=6.879 ; p<0.001)$.

FIG. 5a and $\mathrm{b}$ Changes in total peripheral resistance (TPR dynes. sec. cm. ${ }^{-5}$ ) plotted against changes in heart rate (beats/min.) (Fig. 5a) and per cent changes in cardiac index (l./min. $\left./ \mathrm{m.}^{2}\right)$ (Fig. 5 b) during adrenaline and isoprenaline infusion. Symbols as in Fig. 1 . (For all points plotted in Fig. $5 b$, $r=-0.744 I ; t=3.491 ; p<0.01$.)
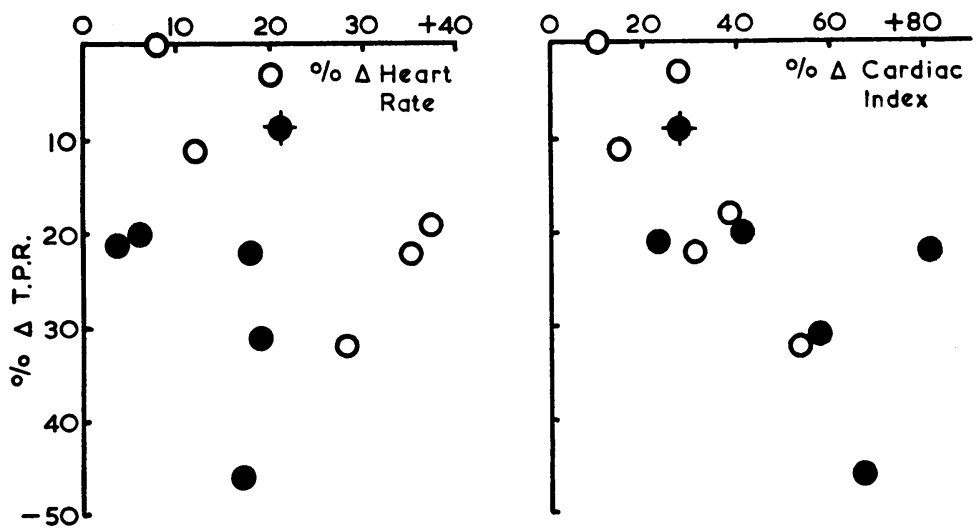

(a) (b) 
rate are shown in Fig. 5a. For a given change in heart rate a greater fall in total peripheral resistance occurs with adrenaline, though no difference between the two drugs was shown when changes in total peripheral resistance were compared with changes in cardiac output (Fig. 5b).

From the data we have obtained, adrenaline appears to be the more effective drug in raising the stroke volume, cardiac output, and brachial arterial systolic and pulse pressures, and in reducing the arteriovenous oxygen difference and total peripheral resistance, especially when these changes are related to increases in heart rate. One disadvantage of isoprenaline was found, namely, it consistently aggravated arterial hypoxaemia (Fordham and Resnekov, 1968). From the information obtained in this study, therefore, adrenaline appears to be preferable to isoprenaline in the treatment of low cardiac output states after aortic valvar replacement.

\section{References}

Allwood, M. J., Keck, E. W., Marshall, R. J., and Shepherd, J. T. (1962). Correlation of hemodynamic events during infusion of epinephrine in man. Fournal of Applied Physiology, 17, 71.

Barcroft, H., and Starr, I. (I95I). Comparison of the actions of adrenaline and noradrenaline on the cardiac output in man. Clinical Science, ro, 295.

Benchimol, A., Lucena, E. G., and Dimond, E. G. (1965). Stroke volume and peripheral resistance during infusion of isoproterenol at a constant fixed heart rate. Circulation, 31, 4I7.

Bradford Hill, A. (1966). Principles of Medical Statistics, 8th ed. Lancet, London.

Bruce, R. A., Cobb, L. A., Morledge, J. H., and Katsura, S. (196I). Effects of posture, upright exercise, and myocardial stimulation on cardiac output in patients with diseases affecting diastolic filling and effective systolic ejection of the left ventricle. American Heart fournal, 6r, 476.

Cox, A. R., Cobb, L. A., and Bruce, R. A. (1963). Differential hemodynamic effects of isoproterenol on mitral stenosis and left ventricular diseases. American Heart fournal, 65, 802.
Cyvin, K., Jahren, G., Jørstad, J., and Retterstøl, N. (1955). Hemodynamic studies on adrenaline. Acta Medica Scandinavica, 153, 67.

Dodge, H. T., Lord, J. D., and Sandler, H. (1960). Cardiovascular effects of isoproterenol in normal subjects and subjects with congestive heart failure. American Heart fournal, 60, 94.

-, and Murdaugh, H. V., Jr. (I957). Cardiovascularrenal effects of isoproterenol in congestive heart failure. (Abstr.) Circulation, 16, 873.

Fordham, R. M. M., and Resnekov, L. (1968). Arterial hypoxaemia. A side-effect of intravenous isoprenaline used after cardiac surgery. Thorax, 23, I9.

-, and Paddle, J. (1968). Haemodynamic effects of intravenous adrenaline sulphate following aortic valvar homograft replacement. British Heart fournal, 30, 350.

Goldberg, L. I., Bloodwell, R. D., Braunwald, E., and Morrow, A. G. (1960). The direct effects of norepinephrine, epinephrine, and methoxamine on myocardial contractile force in man. Circulation, 22, 1125 .

Gorten, R., Gunnells, J. C., Weissler, A. M., and Stead, E. A., Jr. (I961). Effects of atropine and isoproterenol on cardiac output, central venous pressure, and mean transit time of indicators placed at three different sites in the venous system. Circulation Research, 9, 979.

Greene, N. M., and Phillips, A. D. (1957). Metabolic response of dogs to hypoxia in the absence of circulating epinephrine and norepinephrine. American fournal of Physiology, 189, 475.

Harrison, D. C., Glick, G., Goldblatt, A., and Braunwald, E. (1964). Studies on cardiac dimensions on intact, unanesthetised man. IV. Effects of isoproterenol and methoxamine. Circulation, 29, 186.

Moffitt, E. A., Sessler, A. D., and Kirklin, J. W. (1967). Postoperative care in open-heart surgery. fournal of the American Medical Association, 199, 161.

Resnekov, L., Fordham, R., and Ross, D. (I968). Haemodynamic effects of isopropylnoradrenaline sulphate (isoprenaline) following aortic valve homograft replacement. British Heart fournal, 30, 38.

Weissler, A. M., Leonard, J. J., and Warren, J. V. (1959). The hemodynamic effects of isoproterenol in man, with observations on the role of the central blood volume. Fournal of Laboratory and Clinical Medicine, 53, 921.

Witham, A. C., and Fleming, J. W. (I95I). The effect of epinephrine on the pulmonary circulation in man. Fournal of Clinical Investigation, 30, 707. 